\title{
DEPOSITS OF INDIVIDUAL CUSTOMERS - INTRODUCTION TO ANALYSIS
}

\author{
Michał BARTNICKI \\ Silesian University of Technology; Michal.Bartnicki@polsl.pl, ORCID: 0000-0002-0998-4494
}

\begin{abstract}
Purpose: The purpose of the research was an attempt of conducting cross-sectional analysis indicating the distribution of individual customer deposits that are stored on non-savings accounts taking into in the adopted arrangements regarding age and location.

Design/methodology/approach: A preliminary statistical analysis of data showing the structure of individual customers with non-savings deposits, whose average monthly balance exceeded PLN 6,000 was a main research procedure. Data published by the Central Statistical Office (GUS) was used as the comparative background for the presented data. The study showed the analysed accounts from the quantitative perspective and as the amount of balance as well.
\end{abstract}

Findings: An important finding was recognized that significant funds are accumulated on non-savings accounts of individual clients. The most characteristic group here are men aged 55-65 living in the Mazowieckie and Śląskie voivodships.

Originality/value: The basic value of the study is the indication of the main groups in which an investment capital can be sought among individual depositors.

Keywords: non-savings deposits, account structure, account deposits.

\section{Introduction}

Contemporary capital markets give both individual and institutional investors a wide range of instruments to invest and multiply their assets. A significant part of the capital (Dziawgo, 2006; Fatuła, 2007) on the capital market comes from individual investors. Nevertheless, there is a large number of individuals with financial surpluses, which they do not invest but only keep in cash or on non-saving current accounts (Strzelecka, 2010; Iwanicz-Drozdowska, 2008). Contributions to such accounts are essentially non-interest-bearing, or the level of interest rates on those contributions is negligible. As part of the research work, the problem of analysing the structure of non-saving current accounts, whose average monthly balance exceeded PLN 6,000, was taken up. Eight hundred sixty thousand one hundred forty-one non-savings accounts of individual customers with a combined surplus of over PLN 15 billion were analysed. 
It should be noted that this level is conventional for the tests carried out. It was assumed that financial surpluses above PLN 6,000 are financial surpluses, which, without prejudice to the current functioning of an average household, can be invested in a broadly understood capital market, both in the form of short- and long-term investments.

Taking into consideration the amount and range of data of this study, it was mainly focused on the presentation of the data and their primary cluster analysis with basic parameters.

\section{Input data and their preliminary classification}

The study covered 860,141 non-savings bank accounts whose average monthly deposit was at least PLN 6 thousand. For some accounts for current use the value of deposits was very high. It was found that for 45 accounts, the average monthly deposit exceeded PLN 1 million and in individual cases $-4,5$, and 6 million, respectively.

The input data is classified according to several categories, among which balance, age, sex and region may be mentioned.

The balance category was analysed by class. The collection was divided into nine classes (thousands PLN):

1. 6.00-7.49,

2. 7.50-9.99,

3. 10.00-14.99,

4. 15.00-29.99,

5. 30.00-49.99,

6. 50.00-99.99,

7. 100.00-249.99,

8. 250.00-499.99,

9. above 500 .

The age of the account holder was based on the date of birth of the main bank account holder, which means that in the case of an account having several co-owners, only the data of the main holder became relevant. Unfortunately, as part of obtaining data for research, it was not possible to obtain a discriminant that would indicate those accounts that are assigned to one holder and which have many owners. Guided by the division into age categories that are used by the Central Statistical Office (GUS, 2018), categories were grouped every five years, except that all people up to the age of 14 and people older than 100 years old were classified into individual groups.

"Voivodship" category data was established based on the account holder's registration of residence, which means that in the case of an account having several co-owners, only the data of the primary holder became relevant. 
Data for the Gender category was based on the sex of the principal holder, which means that in the case of an account having several co-owners, only the primary owner's data became relevant.

\section{GUS's comparative data}

Open-access GUS databases available on website https://stat.gov.pl/obszarytematyczne/ludnosc/ludnosc/ludnosc-stan-i-struktura-oraz-ruch-naturalny-w-przekrojuterytorialnym-w-2018-r-stan-w-dniu-31-xii,6,25.html were used as a comparative background to the analysed data. Data as at December 31, 2018 were used. Data used in the analysis by category of age, sex, origin are presented in Table 1.

Table 1.

Population by sex and age in 2018 as at 31 XII

\begin{tabular}{|c|c|c|c|c|c|}
\hline Age & Total & Male & Female & Urban areas & Rural areas \\
\hline $0-4$ & $1,916.7$ & 984.7 & 932.0 & $1,127.2$ & 789.5 \\
\hline $5-9$ & $2,005.7$ & $1,030.1$ & 975.5 & $1,144.8$ & 860.9 \\
\hline 10-14 & $1,942.8$ & 996.1 & 946.7 & $1,073.7$ & 869.1 \\
\hline 15-19 & $1,825.0$ & 935.3 & 889.7 & 994.2 & 830.7 \\
\hline $20-24$ & $2,113.9$ & $1,078.7$ & $1,035.2$ & $1,112.0$ & $1,001.9$ \\
\hline $25-29$ & $2,598.8$ & $1,323.4$ & $1,275.4$ & $1,448.7$ & $1,150.1$ \\
\hline 30-34 & $3,024.1$ & $1,533.7$ & $1,490.4$ & $1,853.5$ & $1,170.5$ \\
\hline 35-39 & $3,210.7$ & $1,624.2$ & $1,586.5$ & $1,998.5$ & $1,212.2$ \\
\hline $40-44$ & $2,973.6$ & $1,501.0$ & $1,472.6$ & $1,813.4$ & $1,160.2$ \\
\hline $45-49$ & $2,508.0$ & $1,257.6$ & $1,250.4$ & $1,472.2$ & $1,035.8$ \\
\hline $50-54$ & $2,279.4$ & $1,131.1$ & $1,148.3$ & $1,322.1$ & 957.3 \\
\hline $55-59$ & $2,504.0$ & $1,214.4$ & $1,289.6$ & $1,502.4$ & $1,001.6$ \\
\hline $60-64$ & $2,776.0$ & $1,302.5$ & $1,473.5$ & $1,782.2$ & 993.8 \\
\hline $65-69$ & $2,412.9$ & $1,078.0$ & $1,335.0$ & $1,602.4$ & 810.5 \\
\hline $70-74$ & $1,596.0$ & 672.1 & 923.8 & $1,069.5$ & 526.4 \\
\hline $75-79$ & $1,057.7$ & 402.3 & 655.4 & 691.9 & 365.8 \\
\hline $80-84$ & 876.5 & 296.0 & 580.5 & 562.5 & 314.0 \\
\hline $85-89$ & 538.5 & 160.1 & 378.4 & 338.6 & 199.9 \\
\hline 90-94 & 203.7 & 50.3 & 153.4 & 127.0 & 76.8 \\
\hline $95-99$ & 42.0 & 9.2 & 32.7 & 26.8 & 15.2 \\
\hline 100 and more & 5.1 & 1.1 & 4.0 & 3.6 & 1.5 \\
\hline P OLA N D & $38,411.1$ & $18,581.9$ & $19,829.3$ & $23,067.2$ & $15,343.9$ \\
\hline
\end{tabular}

Source: https://stat.gov.pl/obszary-tematyczne/ludnosc/ludnosc/ludnosc-stan-i-struktura-oraz-ruchnaturalny-w-przekroju-terytorialnym-w-2018-r-stan-w-dniu-31-xii,6,25.html

At the same time, data in other systems, such as territorial division by voivodships, were also used. Considering the limited size of this study and the fact that the data are publicly available, these figures were not presented. 


\section{Analysis by individual categories}

\section{Balance amount}

In total, over 15.5 billion of deposits were gathered on the 860,141 accounts analysed. The analysis according to the amount of balance was conducted in division into 9 groups and looked at quantity and value, supplementing them with structure analysis at the same time. The data are presented in Table 2 .

Table 2.

Number and value of account balances

\begin{tabular}{|c|r|r|r|r|}
\hline $\begin{array}{c}\text { Balance range } \\
\text { thousands PLN }\end{array}$ & $\begin{array}{c}\text { Number of } \\
\text { accounts }\end{array}$ & $\begin{array}{c}\text { Structure of } \\
\text { accounts' number }\end{array}$ & $\begin{array}{c}\text { Accounts' balance } \\
\text { in 10,000 PLN }\end{array}$ & $\begin{array}{c}\text { Structure of } \\
\text { accounts' balances }\end{array}$ \\
\hline $\mathbf{6 . 0 0 - 7 . 4 9}$ & 159,565 & $18.6 \%$ & 106,622 & $6.8 \%$ \\
\hline $\mathbf{7 . 5 0 - 9 . 9 9}$ & 186,643 & $21.7 \%$ & 160,582 & $10.3 \%$ \\
\hline $\mathbf{1 0 . 0 0 - 1 4 . 9 9}$ & 207,773 & $24.2 \%$ & 251,344 & $16.1 \%$ \\
\hline $\mathbf{1 5 . 0 0 - 2 9 . 9 9}$ & 199,526 & $23.2 \%$ & 410,362 & $26.2 \%$ \\
\hline $\mathbf{3 0 . 0 0 - 4 9 . 9 9}$ & 64,085 & $7.5 \%$ & 241,791 & $15.4 \%$ \\
\hline $\mathbf{5 0 . 0 0 - 9 9 . 9 9}$ & 32,103 & $3.7 \%$ & 214,026 & $13.7 \%$ \\
\hline $\mathbf{1 0 0 . 0 0 - 2 4 9 . 9 9}$ & 9,274 & $1.1 \%$ & 131,613 & $8.4 \%$ \\
\hline $\mathbf{2 5 0 . 0 0 - 4 9 9 . 9 9}$ & 975 & $0.1 \%$ & 31,803 & $2.0 \%$ \\
\hline above 500 & 197 & $0.0 \%$ & 17,517 & $1.1 \%$ \\
\hline Summary & 860,141 & $100.0 \%$ & $1,565,660$ & $100.0 \%$ \\
\hline
\end{tabular}

Source: own study.

To better illustrate the analysed data, they were presented in the form of a graph shown in Figure 1.

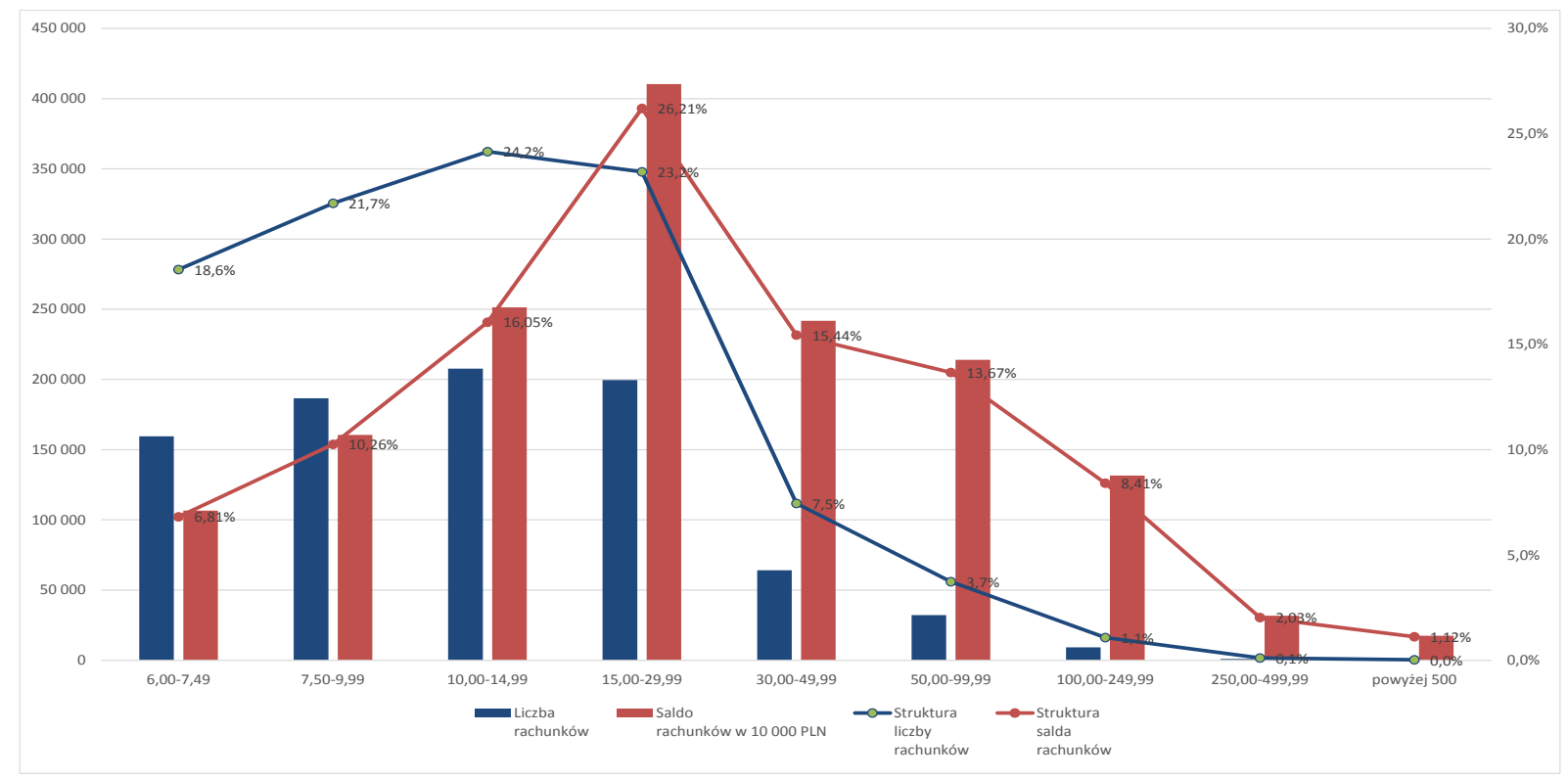

Figure 1. Graph of the number and value of the account balance. Own study.

As can be observed, $87.6 \%$ of the accounts have an average balance of less than PLN 30,000. In the group of PLN 30.00-49.99 thous. there occurs a significant reduction in numbers. This is, of course, on the one hand, because of a higher value range, but also due to 
the fact that for many account holders, exceeding PLN 30,000 of undeveloped funds is an impulse to seek active investment of funds giving additional profit to the investor. It should also be noted that the next higher ranges, despite the small number, accumulate huge deposits, e.g., groups over PLN 30 thousand with $12.4 \%$ of the amount, has over $40 \%$ of the value of deposits. Especially in these groups, one should look for undeveloped investment capital.

\section{Age structure}

As part of grouping data by age category, the population is divided gradationally every five years. The first group starts from the age of 10 because there was no younger person with an average monthly balance higher than the one assumed in the study range (PLN 6,000). The youngest person found who was the primary account holder meeting the criteria was 11 years old, and the oldest was 107 years old. All people over the age of 100 were classified into one group. The exact number of accounts in individual groups is presented in Table 3. Since the number of accounts groups alone does not give a full picture, distinct groups were compared with the population size in a given group provided by the Central Statistical Office (GUS).

Table 3.

The number of accounts in specific age groups compared to the size of the population according to the Central Statistical Office

\begin{tabular}{|c|r|r|r|}
\hline Age category & Number of accounts & Population size & Share in the population \\
\hline $\mathbf{1 0 - 1 4}$ & 7 & $1,942,818$ & $0.000 \%$ \\
\hline $\mathbf{1 5 - 1 9}$ & 547 & $1,824,993$ & $0.030 \%$ \\
\hline $\mathbf{2 0 - 2 4}$ & 8,829 & $2,113,877$ & $0.418 \%$ \\
\hline $\mathbf{2 5 - 2 9}$ & 37,553 & $2,598,818$ & $1.445 \%$ \\
\hline $\mathbf{3 0 - 3 4}$ & 60,403 & $3,024,061$ & $1.997 \%$ \\
\hline $\mathbf{3 5 - 3 9}$ & 68,544 & $3,210,741$ & $2.135 \%$ \\
\hline $\mathbf{4 0 - 4 4}$ & 68,706 & $2,973,557$ & $2.311 \%$ \\
\hline $\mathbf{4 5 - 4 9}$ & 72,349 & $2,508,037$ & $2.885 \%$ \\
\hline $\mathbf{5 0 - 5 4}$ & 87,247 & $2,279,413$ & $3.828 \%$ \\
\hline $\mathbf{5 5 - 5 9}$ & 109,756 & $2,504,016$ & $4.383 \%$ \\
\hline $\mathbf{6 0 - 6 4}$ & 108,197 & $2,776,033$ & $3.898 \%$ \\
\hline $\mathbf{6 5 - 6 9}$ & 76,687 & $2,412,936$ & $3.178 \%$ \\
\hline $\mathbf{7 0 - 7 4}$ & 49,356 & $1,595,967$ & $3.093 \%$ \\
\hline $\mathbf{7 5 - 7 9}$ & 45,712 & $1,057,712$ & $4.322 \%$ \\
\hline $\mathbf{8 0 - 8 4}$ & 35,427 & 876,469 & $4.042 \%$ \\
\hline $\mathbf{8 5 - 8 9}$ & 21,660 & 538,467 & $4.023 \%$ \\
\hline $\mathbf{9 0 - 9 4}$ & 7,699 & 203,734 & $3.779 \%$ \\
\hline $\mathbf{9 5 - 9 9}$ & 1,296 & 41,973 & $3.088 \%$ \\
\hline $\mathbf{1 0 0}$ and more & 166 & 5,102 & $3.254 \%$ \\
\hline Sum & 860,141 & $34,488,724$ & $2.494 \%$ \\
\hline
\end{tabular}

Source: Own study.

To better illustrate the analysed data, they were presented in the form of a graph shown in Figure 2. 


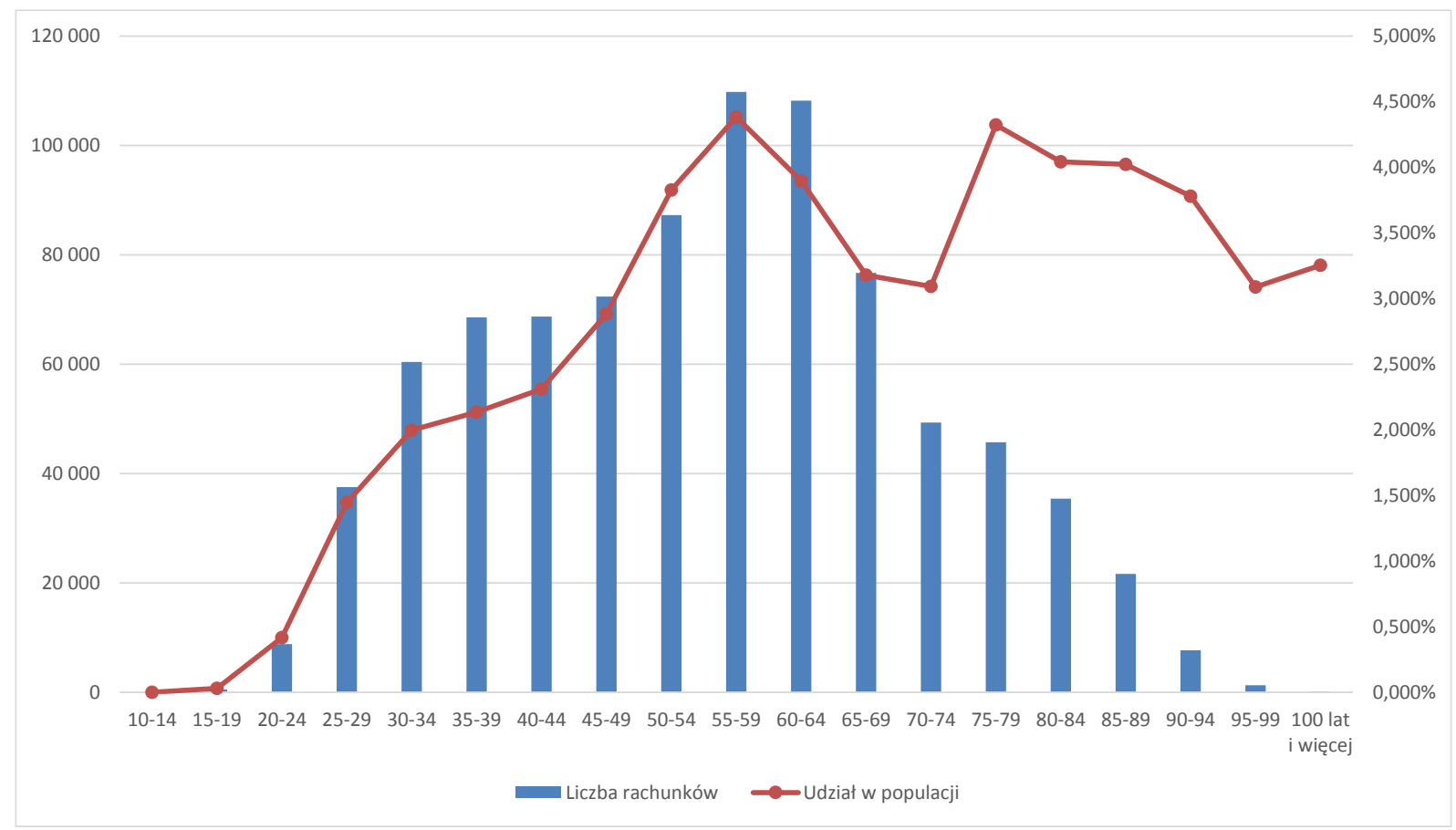

Figure 2. Graph of the number of accounts in individual age groups compared to the size of the population according to GUS.

As can be seen in the figure, the number of people whose average balance of the non-savings account exceeds PLN 6 thousand increases with age. Balances reach maximum values in the ranges of 55-65 years old. This is because in this age range people have relatively the highest salaries very often associated with life promotion and seniority. Then, after reaching retirement age, the trend breaks, and the number of people whose accounts meet the given criteria decreases as the age increases. This decline is primarily due to the mortality of the elderly and hence the declining population in older groups. Due to the decrease in the volume of groups, the data on numerous accounts were compared with the number of people in a given group. One can observe an interesting phenomenon here. The share of people who have non-saving accounts with the determined balance increases systematically with the increase in seniority, reaching maximum values in groups of 55-65 years. After reaching retirement age, the share, as opposed to numbers, stabilizes and remains at a relatively high level in all retirement age groups.

\section{The structure by regions}

As part of grouping data according to geographical distribution, the population was divided according to the territorial division of the country. As part of the regional approach, data were presented in terms of both the number of accounts and the amount of balances. Also, the number of accounts was compared with the population size in a given area. Data in this section are presented in Table 4. 
Table 4.

Number and value of account balances in the territorial division

\begin{tabular}{|c|c|c|c|c|c|c|c|}
\hline Balances' range & $\begin{array}{c}\text { Number } \\
\text { of } \\
\text { accounts }\end{array}$ & $\begin{array}{c}\text { Structure } \\
\text { of } \\
\text { accounts } \\
\text { number }\end{array}$ & $\begin{array}{c}\text { Balance } \\
\text { of } \\
\text { accounts } \\
\text { in PLN } \\
\mathbf{1 0 , 0 0 0}\end{array}$ & $\begin{array}{c}\text { Structure } \\
\text { of } \\
\text { accounts' } \\
\text { balances }\end{array}$ & $\begin{array}{c}\text { Average } \\
\text { balance }\end{array}$ & $\begin{array}{c}\text { Population } \\
\text { size }\end{array}$ & $\begin{array}{c}\text { Share in } \\
\text { the } \\
\text { population }\end{array}$ \\
\hline Opolskie & 16,883 & $2.0 \%$ & 28,125 & $1.8 \%$ & 16,659 & 986,506 & $1.7 \%$ \\
\hline Swiętokrzyskie & 21,654 & $2.5 \%$ & 37,660 & $2.4 \%$ & 17,391 & $1,241,546$ & $1.7 \%$ \\
\hline Lubuskie & 22,793 & $2.6 \%$ & 39,198 & $2.5 \%$ & 17,198 & $1,014,548$ & $2.2 \%$ \\
\hline Podlaskie & 23,108 & $2.7 \%$ & 38,912 & $2.5 \%$ & 16,839 & $1,181,533$ & $2.0 \%$ \\
\hline Podkarpackie & 28,662 & $3.3 \%$ & 48,931 & $3.1 \%$ & 17,072 & $2,129,015$ & $1.3 \%$ \\
\hline Warmińsko-mazurskie & 32,140 & $3.7 \%$ & 55,189 & $3.5 \%$ & 17,171 & $1,428,983$ & $2.2 \%$ \\
\hline Zachodniopomorskie & 35,415 & $4.1 \%$ & 64,891 & $4.1 \%$ & 18,323 & $1,701,030$ & $2.1 \%$ \\
\hline Lubelskie & 38,489 & $4.5 \%$ & 66,177 & $4.2 \%$ & 17,194 & $2,117,619$ & $1.8 \%$ \\
\hline Kujawsko-pomorskie & 38,833 & $4.5 \%$ & 68,417 & $4.4 \%$ & 17,618 & $2,333,523$ & $1.7 \%$ \\
\hline Małopolskie & 46,999 & $5.5 \%$ & 83,196 & $5.3 \%$ & 17,702 & $2,077,775$ & $2.3 \%$ \\
\hline Lódzkie & 66,178 & $6.8 \%$ & 102,646 & $6.6 \%$ & 17,643 & $3,400,577$ & $1.7 \%$ \\
\hline Dolnośląskie & 70,552 & $7.7 \%$ & 115,664 & $7.4 \%$ & 17,443 & $2,466,322$ & $2.7 \%$ \\
\hline Wielkopolskie & 95,200 & $11.1 \%$ & 177,076 & $11.3 \%$ & 18,600 & $3,493,969$ & $2.7 \%$ \\
\hline Śląskie & 106,234 & $12.4 \%$ & 179,145 & $11.4 \%$ & 16,863 & $4,533,565$ & $2.3 \%$ \\
\hline Mazowieckie & 158,692 & $18.4 \%$ & 333,646 & $21.3 \%$ & 21,025 & $5,403,412$ & $2.9 \%$ \\
\hline Final sum & 860,141 & $100.0 \%$ & $1,565,660$ & $100.0 \%$ & 18,202 & $38,411,148$ & $2.2 \%$ \\
\hline
\end{tabular}

Source: own study.

To better illustrate the analysed data, they were presented in the form of a graph shown in Figure 3.

The most significant figures, both in terms of quantity and value, were achieved by the Mazowieckie voivodship, followed by Śląskie and Wielkopolskie voivodships. The lowest figures occurred in the Opolskie Voivodeship. The number of the population present in a given area has an impact on the achieved values. Therefore, the presented data were compared against the population size.

In comparison with the total population, it can be observed that the highest share of people who have non-saving bank accounts with an average balance over PLN 6,000 can be found in the Mazowieckie voivodship (2.9\% of the population), then in the Wielkopolskie and Lódzkie voivodships $(2.7 \%$ of the population)

By far, the smallest share of the analysed accounts occurs in the Podkarpackie voivodship (1.3\% of the population). 


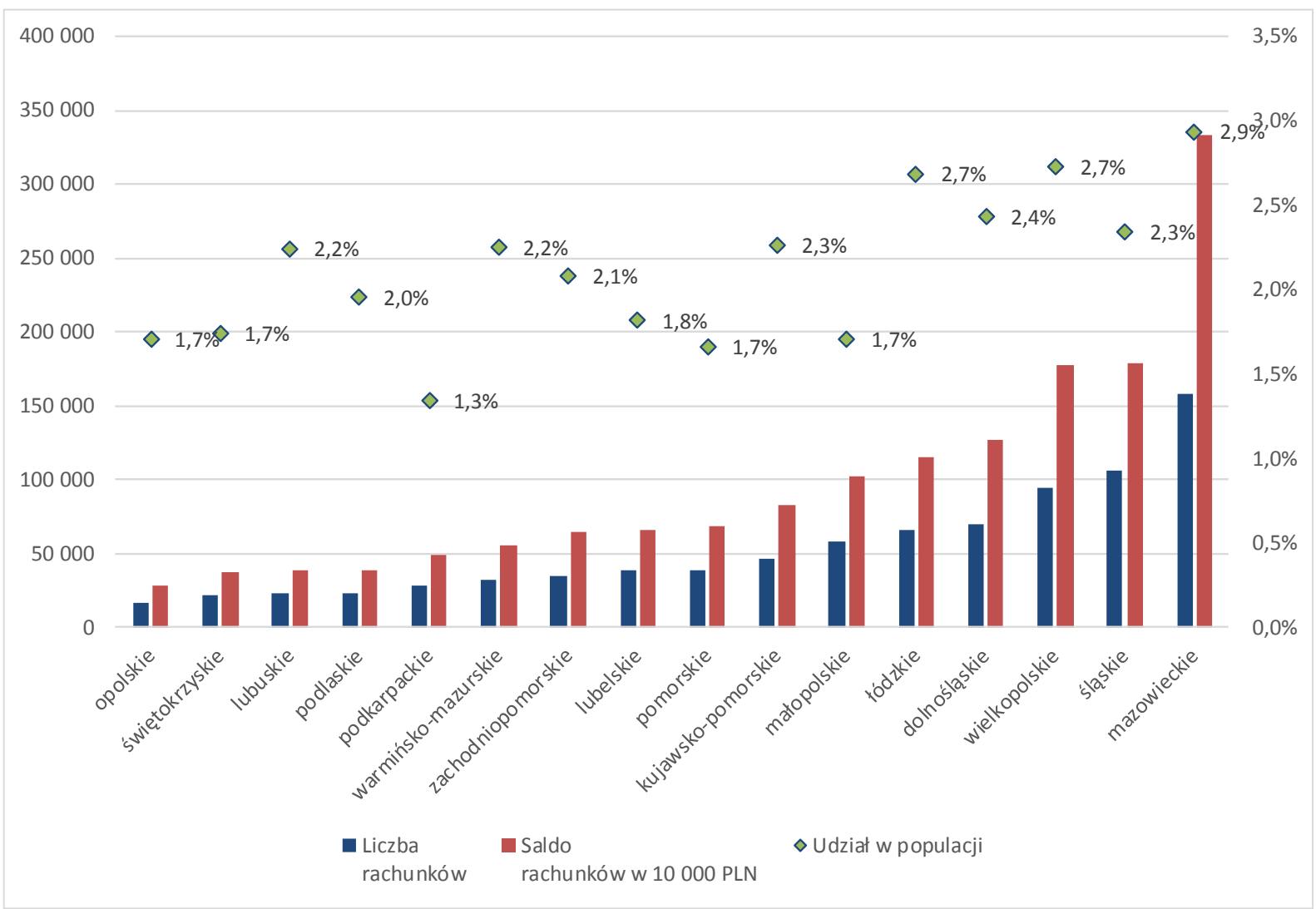

Figure 3. Graph of the number and value of account balances in territorial division.

\section{Structure by sex}

As part of the gender structure analysis, the distribution in the system of groups separated based on balances was checked. Data in this respect ARE presented in Table 5.

Table 5.

The structure of sexes within individual balance groups

\begin{tabular}{|c|c|c|c|c|}
\hline Balance range & $\begin{array}{c}\text { Number of } \\
\text { accounts } \\
\text { Women }\end{array}$ & $\begin{array}{c}\text { Number of } \\
\text { accounts } \\
\text { Men }\end{array}$ & $\begin{array}{c}\text { The share of } \\
\text { accounts } \\
\text { Women }\end{array}$ & $\begin{array}{c}\text { The share of } \\
\text { accounts } \\
\text { Men }\end{array}$ \\
\hline $\mathbf{6 . 0 0 - 7 . 4 9}$ & 85,125 & 74,440 & $53 \%$ & $47 \%$ \\
\hline $\mathbf{7 . 5 0 - 9 . 9 9}$ & 96,699 & 89,944 & $52 \%$ & $48 \%$ \\
\hline $\mathbf{1 0 . 0 0 - 1 4 . 9 9}$ & 104,375 & 103,398 & $50 \%$ & $50 \%$ \\
\hline $\mathbf{1 5 . 0 0 - 2 9 . 9 9}$ & 95,125 & 104,401 & $48 \%$ & $52 \%$ \\
\hline $\mathbf{3 0 . 0 0 - 4 9 . 9 9}$ & 28,825 & 35,260 & $45 \%$ & $55 \%$ \\
\hline $\mathbf{5 0 . 0 0 - 9 9 . 9 9}$ & 14,113 & 17,990 & $44 \%$ & $56 \%$ \\
\hline $\mathbf{1 0 0 . 0 0 - 2 4 9 . 9 9}$ & 3,929 & 5,345 & $42 \%$ & $58 \%$ \\
\hline $\mathbf{2 5 0 . 0 0 - 4 9 9 . 9 9}$ & 395 & 580 & $41 \%$ & $59 \%$ \\
\hline Over 500 & 71 & 126 & $36 \%$ & $64 \%$ \\
\hline Sum & 428,657 & 431,484 & $50 \%$ & $50 \%$ \\
\hline
\end{tabular}

Source: own study.

As seen in the global approach, the gender distribution is in a 50-50 ratio. However, an interesting picture of the situation is drawn in terms of the breakdown into groups according to the average balance. 
It can be seen here that in the lowest ranges women are more often owners of accounts than men. However, as the average balance increases, there is a steady, gradual decrease in this share up to a significant male advantage in groups of accounts with the highest balances (Figure 4).

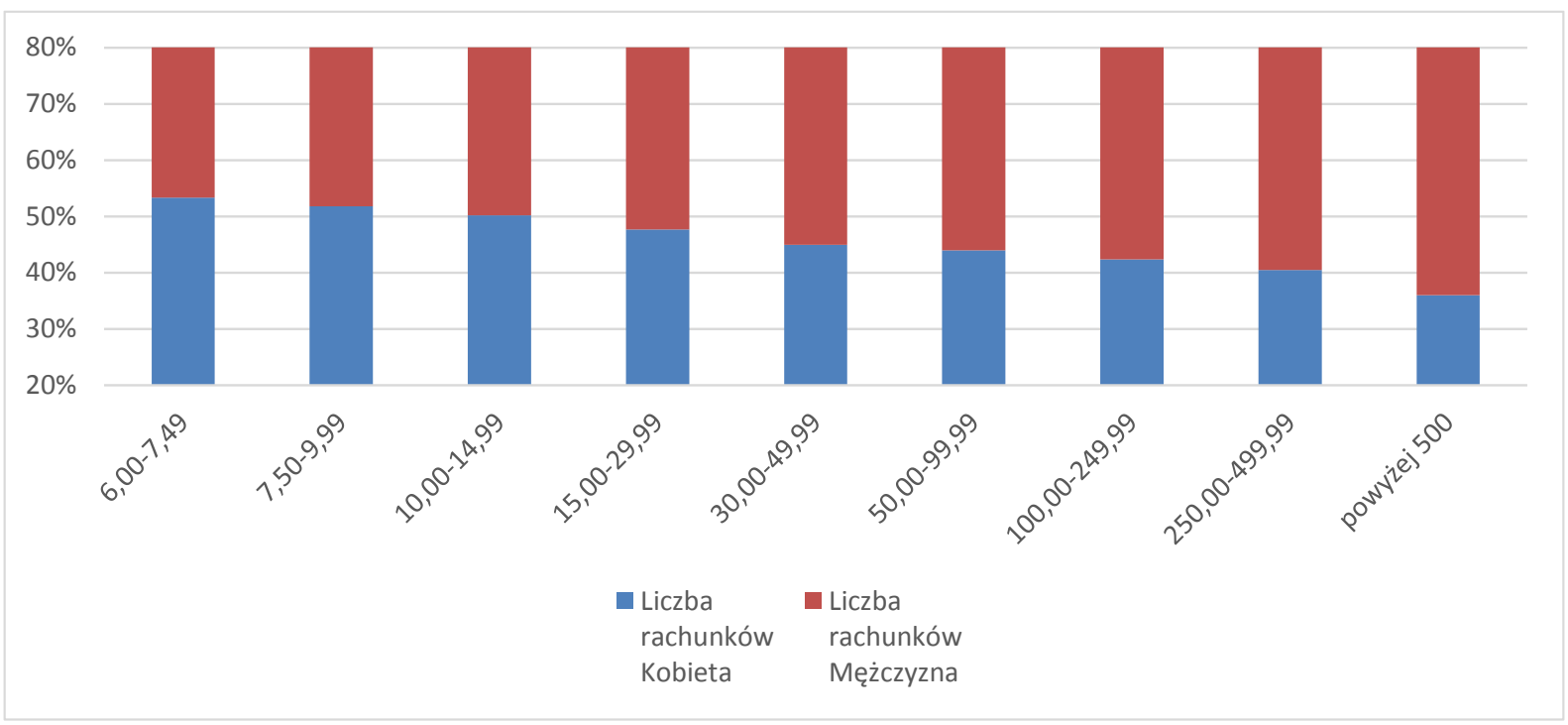

Figure 4 The structure of sexes within individual balance groups.

One can put forward the initial hypothesis that current financing of household expenses is more often carried out from women's accounts. Therefore in the lower groups, they have an advantage. On the other hand, women's investment awareness is greater, and as the average balance increases, they make faster decisions about investing their capital. This phenomenon must be subjected to in-depth analysis, e.g., in an additional system taking into account the age of the account holder, and this will be the subject of further research.

\section{Summary}

Based on the data presented, several exciting conclusions can be drawn. The most important is the statement that individual customers have a very high value of uninvested funds kept on current interest-free accounts. For this study, it was assumed that if the average monthly balance of the existing account is over PLN 6,000 the surplus over this amount can be invested. Potential investors seeking capital may seek it among individuals. Based on the analysis of individual sections, it can be concluded that the potential investor is a man at age of 55-65 (the most significant number of people and the largest percentage of people in this age category) living in the voivodeship: 
1. Mazowieckie (high number of people, very high balances, a very high percentage of people meeting the criteria),

2. Śląskie and Wielkopolskie (a large number of people, high deposits, a high percentage of the population meeting the criteria),

3. Łódzkie (slightly smaller amounts and deposits, but a high percentage of the population meeting the criteria).

It is most challenging to find an investor among women living in the Podkarpackie region.

The presented study is preliminary. An in-depth analysis of broad research material will be the basis for further research, the effects of which will be presented in subsequent articles.

\section{References}

1. Dziawgo, L.(2006). Private banking; Bankowość dla zamożnych klientów. Kraków: Oficyna Ekonomiczna Wolters Kluwer.

2. Fatuła, D. (2007). Struktura depozytów i kredytów bankowych gospodarstw domowych w 2006 roku. Finansowe uwarunkowania decyzji ekonomicznych. Kraków: Krakowska Szkoła Wyższa im. Andrzeja Frycza Modrzewskiego.

3. https://stat.gov.pl/obszary-tematyczne/ludnosc/ludnosc/ludnosc-stan-i-struktura-orazruch-naturalny-w-przekroju-terytorialnym-w-2018-r-stan-w-dniu-31-xii,6,25.html, 01.07.2019.

4. Iwanicz-Drozdowska, M. (2008). Bezpieczeństwo rynku usług finansowych. Warszawa: Perspektywa Unii Europejskiej, Szkoła Główna Handlowa.

5. Strzelecka, A. (2010). Zmiany w strukturze nadwyżek finansowych rolników indywidualnych w Polsce lokowanych w bankach w latach 2000-2010. Zeszyty Naukowe Szkoły Głównej Gospodarstwa Wiejskiego w Warszawie. Ekonomika i Organizacja Gospodarki Żywnościowej, nr 82, p. 257. 